\title{
Perilaku Seksual Berisiko pada Pedagang Bawang Merah di Kecamatan Wanasari Kabupaten Brebes
}

\author{
Nina Maria Desi *), Zahroh Shaluhiyah **), Sutopo Patriajati ***) \\ *) Alumni Fakultas Kesehatan Masyarakat Universitas Diponegoro Semarang \\ Korespondensi : ninamariadesi1988@gmail.com \\ **) Magister Promosi Kesehatan Universitas Diponegoro Semarang \\ ***) Magister Ilmu Kesehatan Masyarakat Universitas Diponegoro Semarang
}

\begin{abstract}
ABSTRAK
Tingkat migrasi penduduk yang makin tinggi mengakibatkan populasi berisiko tertular infeksi menular seksual juga meningkat. Dari studi pendahuluan yang dilakukan terhadap pedagang bawang merah di wilayah Kec. Wanasari Kab. Brebes terungkap bahwa pengetahuan mengenai perilaku seksual beresiko kurang dan perilaku seksual beresiko tanpa kondom yang tinggi. Penelitian ini merupakan penelitian deskriptif analitik kuantitatif dengan rancangan cross sectional, metode pengumpulan data dengan penyebaran kuisioner untuk mencari gambaran perilaku seksual berisiko. Sampel penelitian yaitu pedagang bawang merah di Kec. Wanasari Kab. Brebes yaitu sebesar 120 orang. Sebanyak 86,7\% responden berperilaku seksual berisiko IMS. 70,8\% responden berumur $\geq 32$ tahun dengan pendidikan rendah sebanyak 57,5\% dan belum menikah sebanyak 52,5\%. Sebagian besar responden berpengetahuan kurang baik dan 61,7\% melakukan kegiatan berisiko untuk mengisi waktu luang. Variabel yang berhubungan terhadap perilaku seksual berisiko IMS adalah umur dan kegiatan pengisi waktu luang. Analisis multivaritat menunjukan factor yang paling berpengaruh adalah umur, kegiatan pengisi waktu luang dan religiusitas.

Saran bagi Dinas Kesehatan Kabupaten Brebes lebih meningkatkan pengetahuan para pedagang bawang dalam hal perilaku seksual berisiko dan memfasilitasi para pedagang untuk mengisi waktu luang dengan hal yang bermanfaat dan terhindar dari perilaku seksual berisiko.
\end{abstract}

Kata Kunci : Pedagang bawang, Infeksi Menular Seksual

\section{ABSTRACT}

SEXUAL BEHAVIOR AT RISK OF ONION TRADERS IN WANASARI, BREBES

Along with the times, the population at high risk of sexually transmitted infections increase rapidly. From a preliminary study in the district Wanasari Brebes revealed that their knowledge about sexual behavior said to be low risk and lots of sexual risk behavior without condom. This research is descriptive quantitative analytical with cross-sectional design study, methods for collecting the data by distributing questionnaires to find a picture on the risky sexual behaviors of respondent. The sample in this research is 120 people. $86,7 \%$ respondent has risky sexual behavior. 70,8\% of respondent is above 32 years old with low education as much as 57,5\% and not marriage yet 52,5\%. 61,7\% of respondent has risky behavior in their leisure time. Variables that significantly relationship against sexual behavior are ages and leisure activity.based on multivariate analisys, variables that strongly connected to sexual behavior is ages, leisure activity, and religiousity.

Advice given to Departemen Kesehatan Brebes for further enhance the knowledge of onion traders in terms of risky sexual behavior, include facilitating spare time with things that are more useful to avoid risky sexual behavior.

Keyword: Behavior, sexual risk, Brebes 


\section{PENDAHULUAN}

IMS sering juga disebut sebagai penyakit kelamin, yaitu penyakit-penyakit yang sebagian besar ditularkan melalui hubungan seksual atau hubungan kelamin. Sebelum dikenal sebagai infeksi menular seksual, jenis penyakit ini sudah cukup lama dikenal dengan sebutan penyakit kelamin (venereal disease) yang berasal dari kata Venus yang berarti dewi cinta. Saat itu penyakit kelamin yang dikenal baru sifilis (syphilis) dan gonore (gonorrhea), sedangkan istilah infeksi menular seksual baru dikenal setelah ditemukannya jenis penyakit kelamin selain kedua jenis penyakit di atas. IMS dikenal pula dengan sebutan Penyakit Akibat Hubungan Seksual (PHS) atau Sexually Transmitted Diseases (STD). (Kemenkes RI, 2013).

Selama dekade terakhir infeksi menular seksual ini mengalami peningkatan insidensi yang cukup pesat di berbagai negara di seluruh dunia. Contohnya, tahun 1995 kasus baru gonore di Amerika Serikat sebanyak 62.150.000 kasus dan pada tahun 1999 kasus ini meningkat menjadi 62.350.000 kasus. Pada tahun 1999, WHO memperkirakan terdapat 340 juta kasus infeksi menular seksual baru yang terjadi terutama pada pria dan wanita yang berusia 15 - 49 tahun. Pada tahun 2008, dilaporkan 1.210.523 kasus infeksi klamidia di Amerika Serikat.
Jumlah ini meningkat sebanyak $9,2 \%$ bila dibandingkan dengan data pada tahun 2007. Tidak hanya infeksi klamidia, insidensi sipilis pun mengalami peningkatan yang pesat yaitu sebanyak 67\% sejak tahun 2004 dan memuncak pada tahun 2008 dengan jumlah 13.500 kasus termasuk kejadian sipilis primer dan sekunder. Di Indonesia sendiri, telah banyak laporan mengenai prevalensi infeksi menular seksual ini, beberapa laporan yang ada di beberapa lokasi antara tahun 1999 sampai 2001 menunjukkan prevalensi infeksi gonore dan klamidia yang tinggi antara 20\%-35\%. Selain klamidia, sifilis maupun gonore, infeksi HIV/AIDS saat ini juga menjadi perhatian karena peningkatan angka kejadiannya yang terus bertumbuh dari waktu ke waktu dan dapat digambarkan sebagai fenomena gunung es.(Silitonga, 2009).

Di Indonesia Angka IMS saat ini cenderung meningkat, penyebarannya sulit ditelusuri sumbernya, sebab tidak pernah dilakukan registrasi terhadap penderita yang ditemukan, adapun jumlah penderita yang sempat terdata hanya sebagian kecil dari jumlah penderita sesungguhnya. Banyak kasus yang asimtomatik (tanpa gejala yang khas) terutama pada wanita. Meskipun demikian program pencegahan dan pemberantasan infeksi menular seksual harus diberi prioritas yang tinggi karena infeksi menular seksual membawa 
konsekuensi yang tinggi yaitu mempermudah penularan HIV/AIDS, sedangkan infeksi klamidia, ulkus, gonorhoe, uretritis non gonorhoe, sifilis, dan trikomoniasis dapat meningkatkan resiko penularan $H I V$ antara $2-9$ kali. Penderita infeksi menular seksual dengan ulkus genital mempunyai resiko $2-5$ kali dibanding penderita tanpa ulkus.(Kemenkes RI, 2009)

Hasil Surveilen Terpadu Biologis dan Perilaku Tahun 2011 yang dilaksanakan di $23 \mathrm{Kota} /$ Kabupaten di 11 Provinsi dimana sebagian besar Kota/Kabupaten terpilih sama dengan kota/kabupaten (lokasi) STBP Tahun 2007, di peroleh hasil bahwa prevalensi HIV tertinggi terdapat pada Penasun (41\%), diikuti waria (22\%), WPSL (10\%), LSL $(8 \%)$, WBP $(3 \%)$ WPSTL $(3 \%)$ dan Pria Potensial Risti (0,7\%). Prevalensi Sifilis tertinggi ditemukan pada Waria (25\%), diikuti WPSL (10\%), LSL (9\%), WBP (5\%), Pria Potensial Risti (4\%), WPSTL (3\%) dan Penasun (2\%). Prevalensi Gonore tertinggi pada WPSL (38\%), kemudian diikuti oleh waria (29\%), LSL (21\%), dan WPSTL (19\%). Prevalensi Klamidia tertinggi pada WPSL dan WPSTL (masing-masing 41\%) diikuti oleh waria (28\%) dan LSL (21\%). Prevalensi Gonore dan atau Klamidia berkisar antara $33 \%$ (LSL) dan 56\% (WPSL).(Dadun, 2011).
Di Jawa Tengah Kasus HIV-AIDS terus mengalami peningkatan hingga desember 2014 telah dilaporkan 10.804 kasus dengan rincian HIV 5.871 kasus dan AIDS 4.933 kasus, dengan angka kematian sebanyak 1.192 kasus. Jumlah tersebut menempatkan Propinsi Jawa Tengah pada peringkat ke 6 dengan kasus HIV dan AIDS terbanyak di Indonesia. Dari jumlah kasus tersebut, terkhusus di Jawa Tengah, lebih dari $60 \%$ penderita adalah perempuan. Sedangkan jumlah kasus IMS di Provinsi Jawa Tengah tahun 2014 sebanyak 8.590 kasus, lebih sedikit dibanding tahun sebalumnya. Meskipun demikian kemungkinan kasus yang sebenarnya di populasi masih banyak yang belum terdeteksi. Program pencegahan dan pengendalian Penyakit Menular Seksual mempunyai target bahwa seluruh kasus IMS yang ditemukan harus diobati sesuai standar. (Dinkes Jawa Tengah, 2014)

Menurut Dinas Kesehatan Kabupaten Brebes sejak Juni 2008 hingga Desember 2014 jumlah penderita penyakit infeksi menular seksual paling banyak pada laki-laki sekitar $68 \%$ dan perempuan sekitar 32\%, sedangkan angka tertinggi menurut jenis pekerjaan adalah kelompok wiraswasta karena mayoritas masyarakat Kabupaten Brebes adalah petani bawang merah dan pedagang bawang merah. Angka kejadian IMS cenderung terus meningkat dikarenakan wilayah Kabupaten 
Brebes berbatasan langsung dengan Kota Tegal, Kabupaten Banyumas dan Kota Cirebon yang merupakan sentral pembangunan ekonomi, pendidikan, industri dan pusat hiburan seperti hotel, café dan restoran, panti pijat, diskotik, karaoke, salon kecantikan, pusat perbelanjaan dan lokalisasi. Hal ini membuat masyarakat Kabupaten Brebes lebih mudah dalam melakukan perilaku beresiko IMS dikarenakan terdapatnya akses-akses yang mudah didapatkan di kota-kota yang berbatasan langsung dengan wilayahnya, khususnya ketika mereka memiliki banyak uang dari keuntungan penjualan bawang merah. Dengan uang yang mereka miliki, pedagang bawang merah yang mayoritas laki-laki dengan mobilitas tinggi, dapat dikategorikan laki-laki high risk man yang beresiko dapat melakukan perbuatan beresiko IMS. (Dinkes Kab Brebes, 2014)

\section{METODE}

Metode penelitian yang digunakan dalam penelitian ini adalah metode deskriptif analitik kuantitatif dengan pendekatan Cross Sectional. Populasi dalam penelitian ini adalah pedagang bawang merah yang telah bekerja sebagai pedagang bawang merah selama lebih dari 5 tahun dan tinggal di Kecamatan Wanasari Kabupaten Brebes. Adapun besar sampel adalah 120 orang. Variable independen adalah usia, pendidikan, penghasilan, status perkawinan, pengetahuan tentang IMS, pengetahuan tentang HIV/AIDS, kegiatan pengisi waktu luang, sikap terhadap seksualitas, religiusitas, sikap dan perilaku teman, akses informasi dan fluktuasi harga. Sedangkan variabel dependen adalah perilaku seksual berisiko IMS. Pengambilan data primer dilakukan selama 3 bulan dengan angket untuk menjamin kenyamanan responden dalam mengisi pertanyaan-pertanyaan yang sensitive untuk ditanyakan melalui wawancara. Untuk membuktikan keabsahan kuisioner yang digunakan dalam penelitian ini perlu dilakukan uji coba kuisioner pada 30 pedagang bawang di Kecamatan Jatibarang Kabupaten Brebes. Uji validitas dilakukan dengan uji korelasi product moment, sedangkan uji reliabilitas menggunakan alfha cronbach. Analisis data yang digunakan analisis univariat, bivariat dengan uji $C h i-s q u a r e$ dan multivariat dengan uji regresi logistik dengan metode Enter. 


\section{HASIL DAN PEMBAHASAN}

Tabel 1. Analisis Deskriptif Variabel yang Mempengaruhi Perilaku Seksual Berisiko IMS

Pedagang Bawang Merah

\begin{tabular}{|c|c|c|c|c|}
\hline No & Variabel & $\mathbf{F}$ & $\%$ & p-value \\
\hline \multirow[t]{3}{*}{1} & \multicolumn{3}{|l|}{ Umur } & \multirow{3}{*}{0,991} \\
\hline & $-<32$ tahun & 35 & 29,2 & \\
\hline & $-\geq 32$ tahun & 85 & 70,8 & \\
\hline \multirow[t]{3}{*}{2} & \multicolumn{3}{|l|}{ Pendidikan } & \multirow{3}{*}{0,727} \\
\hline & - Rendah & 69 & 57,5 & \\
\hline & - Tinggi & 51 & 42,5 & \\
\hline \multirow[t]{3}{*}{3} & \multicolumn{3}{|l|}{ Penghasilan } & \multirow{3}{*}{0,677} \\
\hline & $-<$ Rp.120.000,- & 54 & 45,0 & \\
\hline & $-\geq$ Rp.120.000,- & 66 & 55 & \\
\hline \multirow[t]{3}{*}{4} & \multicolumn{3}{|l|}{ Status Perkawinan } & \multirow{3}{*}{0,945} \\
\hline & - Belum Kawin & 63 & 52,5 & \\
\hline & - Kawin & 57 & 47,5 & \\
\hline \multirow[t]{3}{*}{5} & \multicolumn{3}{|c|}{ Pengetahuan tentang IMS } & \multirow{3}{*}{0,783} \\
\hline & - Kurang Baik & 60 & 50 & \\
\hline & - Baik & 60 & 50 & \\
\hline \multirow[t]{3}{*}{6} & \multicolumn{3}{|c|}{ Pengetahuan tentang HIV } & \multirow{3}{*}{0,781} \\
\hline & - Kurang Baik & 68 & 56,7 & \\
\hline & - Baik & 52 & 43,3 & \\
\hline \multirow[t]{3}{*}{7} & \multicolumn{3}{|c|}{ Kegiatan Pengisi Waktu Luang } & \multirow{3}{*}{0.016} \\
\hline & - Berisiko IMS & 74 & 61,7 & \\
\hline & - Tidak Berisiko IMS & 46 & 38,3 & \\
\hline \multirow[t]{3}{*}{8} & \multicolumn{3}{|c|}{ Sikap terhadap seksualitas } & \multirow{3}{*}{0,403} \\
\hline & - Permisif & 52 & 43,3 & \\
\hline & - Tidak Permisif & 68 & 56,7 & \\
\hline \multirow[t]{3}{*}{9} & \multicolumn{3}{|l|}{ Religiusitas } & \multirow{3}{*}{0,190} \\
\hline & - Kurang Religius & 59 & 49,2 & \\
\hline & - Religius & 61 & 50,8 & \\
\hline \multirow[t]{3}{*}{10} & Sikap teman & & & \\
\hline & - Permisif & 53 & 44,2 & 0,835 \\
\hline & - Tidak Permisif & 67 & 55,8 & \\
\hline 11 & Akses Informasi & & & \\
\hline & - Tidak tersedia & 61 & 50,8 & 0.730 \\
\hline & - Tersedia & 59 & 49,2 & \\
\hline 12 & Fluktuasi Harga & & & \\
\hline & - Berpengaruh & 42 & 35 & 0,885 \\
\hline & - Kurang berpengaruh & 78 & 65 & \\
\hline
\end{tabular}




\section{Umur}

Berdasarkan mayoritas responden $70,8 \%$ berusia $\geq 32$ tahun dan berdasarkan analisis bivariat diperoleh nilai $p$ value 0,991yang menyatakan bahwa ada hubungan yang signifikan antara umur dengan perilaku seksual berisiko IMS pada pedagang bawang merah di Kecamatan Wanasari Kabupaten Brebes. Hasil statistik pada penelitian ini sesuai dengan hasil penelitian Nadra Aniswah (2016), yang menyebutkan ada hubungan yang signifikan antara umur dengan perilaku seksual. Hal ini dapat disebabkan secara psikologis seseorang yang semakin dewasa atau bertambah umurnya cenderung lebih mandiri dalam pengambilan keputusan untuk dirinya sendiri dan tidak terlalu mementingkan pendapat orang lain. Semakin dewasa seseorang biasanya memiliki pemikiran dalam hal kebebasan dan didukung dengan kurangnya kontrol dari keluarga dan masyarakat atas dirinya.(Budiarto, 2003).

Hasil penelitian menunjukkan persentase responden yang memiliki perilaku seksual berisiko lebih banyak terdapat pada kelompok responden yang berumur $\geq 29$ tahun sebanyak 94,1\% dibandingkan responden kelompok yang berumur $<29$ tahun sebayak 71,4\%. Pada usia dewasa muda, seseorang biasanya sudah menemukan konsep dirinya. Berbeda dengan usia muda yang sedang mencari jati diri dan mudah terpengaruh dengan lingkungan dan teman sebayanya, termasuk dalam melakukan hubungan seksual yang tidak aman. Menurut Hurlock, semakin cukup umur tingkat kematangan dan kekuatan seseorang akan lebih matang dalam berfikir dan bekerja.(Ririanti, 2009).

Penelitian ini sesuai dengan teori Lawrence Green dimana menurut Green umur termasuk faktor yang mempermudah (predisposing factor) terjadinya perubahan perilaku seseorang. ${ }^{30)}$ Didalam Model precede-proceed, faktor pemungkin digambarkan sebagai faktor-faktor yang memungkinkan (membuat lebih mudah) individu atau populasi untuk merubah perilaku atau lingkungan mereka. (Green, 2000)

\section{Pendidikan}

Berdasarkan hasil penelitian mayoritas pendidikan responden adalah $57,5 \%$ berpendidikan rendah. Pendidikan adalah tingkatan pendidikan tertinggi secara formal yang dinyatakan lulus, dikatakan berpendidikan tinggi bila lulus SLTA dan Perguruan Tinggi sedangkan rendah bila lulusan SMP, SD dan tidak sekolah. Hasil tabulasi silang responden yang memiliki perilaku seksual berisiko lebih banyak terdapat pada kelompok responden yang memiliki pendidikan rendah sebanyak $88,4 \%$ dibandingkan responden kelompok yang berpendidikan 
tinggi sebayak 86,3\%. Berdasarkan hasil

Chi square didapatkan $p$ value sebesar 0,727 yang berarti tidak ada hubungan antara variabel pendidikan dengan perilaku seksual berisiko IMS pada pedagang bawang merah di Kecamatan Wanasari Kabupaten Brebes.

Meskipun hasil analisis menunjukkan tidak ada hubungan antara pendidikan dengan perilaku berisiko IMS, hal ini dapat disebabkan oleh faktor lain seperti yang mendukung seperti pendapatam, fluktuasi harga dan kegiatan pengisi waktu luang. Hasil penelitian ini sesuai dengan penelitian dilakukan oleh Pratiwi dan Basuki pada tahun 2011 bahwa pada pria bahwa pada lebih banyak pria berpendidikan rendah yang berperilaku seksual tidak aman dibandingkan pria dengan pendidikan tinggi dan menengah. Hasil penelitian ini tidak sesuai dengan penelitian yang dilakukan oleh Dewi, yang menunjukkan ada hubungan yang signifikan antara tingkat pendidikan dengan perilaku seksual, dimana pendidikan yang lebih tinggi memiliki peluang lebih besar 1,89 kali lebih besar dibandingkan pendidikan yang lebih rendah dalam hal perilaku seksual berisiko.(Hakim, 2012).

Seseorang dengan pendidikan tinggi biasa saja beranggapan bahwa sudah memiliki cukup pengetahuan tentang risiko yang akan dihadapi, walaupun belum tentu informasi yang didapatkan selama ini sudah benar. Pendidikan yang tinggi akan menimbulkan keberanian dan kepercayaan diri yang lebih besar pada diri seseorang untuk membuat keputusan atas tindakannya. Hal sebaliknya, pendidikan rendah akan membuat kepercayaan diri seseorang dalam menghadapi risiko juga akan rendah. (Budiarto, 2003)

\section{Penghasilan}

Berdasarkan hasil penelitian bahwa sebanyak 120 orang didapatkan data bahwa sebagian besar responden yang memiliki penghasilan $\geq$ Rp.120.000 yaitu sebanyak $55 \%$ responden. Hasil uji chi square didapatkan $p$ value $=0,677$ dimana $\mathrm{p}>0,05$, $\mathrm{H}_{0}$ diterima sehingga tidak ada hubungan yang bermakna antara variabel penghasilan dengan perilaku seksual berisiko IMS. Dari hasil tabulasi silang menunjukkan bahwa $55 \%$ responden yang memiliki perilaku seksual berisiko IMS dengan pendapatan $\geq$ Rp.120.000. Hasil penelitian ini secara umum tidak sejalan dengan penelitian Desy Qomarasari bahwa mayoritas seseorang dengan pendapatan keluarga rendah cenderung lebih banyak melakukan perilaku seksual $(32,2 \%)$. Hasil analisis bivariat menunjukkan hal yang berbeda dimana adanya hubungan pendapatan keluarga dengan perilaku seksual dan secara statistik signifikan $(\mathrm{p}<0,001)$. Hasil ini mungkin akan berbeda jika dilakukan di tempat yang berbeda, karena 
karakteristik dari responden berbeda dan lebih beraneka ragam. Sehingga untuk pendapatan keluarga ini masih ada faktorfaktor lain yang mempengaruhinya yang belum diteliti oleh peneliti.

Tuntutan kehidupan terkadang menjadikan seseorang tanpa mengenal kelas sosial ekonomi menjadi agresif. Seseorang cenderung bebas dalam menemukan dan belajar sendiri serta mencari pengalaman sendiri. Dengan perekonomian keluarga yang rendah membuat remaja cenderung melakukan perilaku seksual agar pasangannya dapat memenuhi segala sesuatu yang ia butuhkan yang tidak bisa di dapat di keluarga. Dalam penelitian ini pendapatan pedagang bawag merah tidak diikuti dengan perbedaan perilaku seksual, karena ada factor-faktor lain yang juga mempengaruhi responden dalam melakukan perilaku beresiko IMS. (Ririanti, 2009).

\section{Status Perkawinan}

Berdasarkan hasil penelitian menunjukkan bahwa jumlah responden sebanyak 120 orang didapatkan data bahwa sebagian besar responden pada status pernikahan yang belum kawin yaitu sebanyak $52,5 \%$ responden. Status pernikahan adalah status pernikahan responden yang hendak diteliti yaitu kawin (beristri dan duda) serta belum kawin. Berdasarkan tabulasi silang diketahui bahwa persentase responden yang memiliki perilaku seksual berisiko lebih banyak terdapat pada kelompok responden pada status pernikahan belum kawin sebanyak $87,7 \%$ dibandingkan responden kelompok responden pada status pernikahan kawin sebanyak 87,3\%. Hasil uji chi square didapatkan $p$ value $=0,945$ dimana $\mathrm{p}>0,05, \mathrm{H}_{0}$ diterima sehingga tidak ada hubungan yang bermakna antara variabel status pernikahan dengan perilaku seksual berisiko IMS.

Status kawin tidak akan menjamin seseorang dalam berperilaku seksual. Banyak faktor yang mendorong seseorang dalam berperilaku. Dalam hal ini adalah faktor pergaulan sehari-hari responden dimana dalam kesehariannya selalu beraktifitas diluar rumah. Faktor pendukung lainnya adalah lingkungan yang memungkinkan seseorang dalam berperilaku seksual berisiko.

\section{Pengetahuan tentang IMS}

Berdasarkan hasil penelitian menunjukkan bahwa responden yang memiliki tingkat pengetahuan tentang IMS yang kurang yaitu sebanyak 50\% responden. Pengetahuan tentang IMS yaitu pemahaman responden untuk menjawab segala sesuatu yang berkaitan dengan pengertian IMS, gejala-gejala IMS, penyebab IMS, cara penularan IMS, cara pencegahan IMS, dan cara pengobatan IMS. Berdasarkan hasil tabulasi silang diketahui bahwa persentase responden 
yang memiliki perilaku seksual berisiko lebih ban yak terdapat pada kelompok responden dengan tingkat pengetahuan baik tentang IMS sebanyak $88,3 \%$ dibandingkan responden kelompok responden dengan tingkat pengetahuan kurang tentang IMS sebanyak 86,7\%. Hasil uji chi square didapatkan $p$ value $=0,783$ dimana $p>0,05, \mathrm{H}_{0}$ diterima sehingga tidak ada hubungan yang bermakna antara variabel tingkat pengetahuan tentang IMS dengan perilaku seksual berisiko IMS.

Hasil penelitian ini sejalan dengan penelitian oleh Ika Ayu dkk (2014) yang menunjukkan tidak ada hubungan antara pengetahuan dengan perilaku seks pranikah dengan nilai $p=0,610(p>0,05)$. Seseorang yang memiliki pengetahuan yang baik mengenai justru melakukan perilaku seks pranikah sebesar $62,8 \%$. Dari presentase sebesar $62,8 \%$ tersebut, yang melakukan perilaku seks pranikah yang berisiko tinggi sebesar $37,8 \%$ dan yang melakukan perilaku seks pranikah yang berisiko rendah sebesar $25 \%$.

Hal ini juga sejalan dengan penelitian Ristiya dkk (2011) bahwa sebanyak apapun pengetahuan tentang perilaku seks pranikah, tidak berpengaruh banyak terhadap perilaku seks pranikah pada mahasiswa. Semakin baik pengetahuan tentang perilaku seks pranikah yang dimiliki oleh seorang mahasiswa akan semakin permisif pula perilaku seks pranikahnya. Hal ini ada kaitannya dengan pola berfikir mahasiswa yang sudah masuk dalam batas kedewasaan, dimana mereka memiliki pengetahuan yang lebih baik tentang perilaku seks yang bertanggung jawab dan tindakan pencegahan yang tepat, misalnya tentang penggunaan alat kontrasepsi. Hal ini menyebabkan mereka merasa dapat menyalurkan hasrat seksual walaupun belum menikah, tetapi dengan cara yang lebih bertanggung jawab.(Andisti,2008).

\section{Pengetahuan tentang HIV}

Pengetahuan tentang HIV yaitu pemahaman responden untuk menjawab segala sesuatu yang berkaitan dengan pengertian HIV, gejala-gejala HIV, penyebab HIV, penularan HIV, cara pencegahan HIV dan cara pengobatan HIV-AIDS. Pada penelitian ini responden yang memiliki tingkat pengetahuan tentang HIV yang kurang yaitu sebanyak 56,7\% responden. Sedangkan hasil tabulasi silang menunjukkan bahwa perilaku seksual berisiko lebih banyak terdapat pada kelompok responden dengan tingkat pengetahuan kurang tentang HIV sebanyak 88,2\% dibandingkan responden kelompok responden dengan tingkat pengetahuan baik tentang HIV sebanyak $86,5 \%$. Hasil uji chi square didapatkan $p$ value $=0,781$ dimana $p>0,05, \mathrm{H}_{0}$ diterima sehingga tidak ada hubungan yang bermakna antara 
variabel tingkat pengetahuan tentang HIV dengan perilaku seksual berisiko IMS.

Hasil ini sesuai dengan penelitian oleh Ika Nur didapatkan $\mathrm{p}=0.905$ berarti tidak ada hubungan antara pengetahuan tentang kesehatan reproduksi, IMS, dan HIV/AIDS. Hasil yang sama diperoleh dari responden remaja SMA Negeri 1 Purwokerto. Uji statistik pada responden ini didapatkan $\mathrm{p}=1.000$, berarti tidak ada hubungan antara pengetahuan tentang kesehatan reproduksi, IMS dan HIV/AIDS. Jumlah responden yang berpengetahuan rendah dan melakukan perilaku seksual pranikah sebanyak 9 (29\%), sedangkan responden yang berpengetahuan tinggi dan melakukan perilaku seksual pranikah sebanyak 27 (28.7\%).

Pengetahuan mungkin bukanlah faktor yang berpengaruh langsung terhadap perilaku seksual berisiko IMS. Seperti yang dijelaskan oleh Bandura (1990) bahwa perilaku tersebut tidak merupakan hasil langsung dari pengetahuan atau ketrampilan, melainkan suatu proses penilaian yang dilakukan seseorang dengan menyatukan ilmu pengetahuan, harapan, status emosi, pengaruh sosial dan pengalaman yang didapat sebelumnya untuk menghasilkan suatu penilaian atas kemampuan mereka dalam menguasai situasi yang sulit. (Andisti, 2008).

\section{Kegiatan Pengisi Waktu Luang}

Kegiatan waktu luang adalah kegiatan responden untuk mengisi waktu luang yang berpotensi meningkatkan perilaku seksual berisiko. Pada penelitian ini diketahui bahwa sebagian besar responden yang memiliki kegiatan waktu luang dengan berisiko IMS yaitu sebanyak $61,7 \%$. Berdasarkan hasil tabulasi silang diketahui persentase responden yang memiliki perilaku seksual berisiko lebih banyak terdapat pada kelompok responden dengan kegiatan waktu luang yang berisiko sebanyak 93,2\% dibandingkan responden kelompok responden dengan kegiatan waktu luang yang kurang berisiko sebanyak 78,3\%. Hasil uji chi square didapatkan $p$ value $=0,016$ dimana $p>0,05$, $\mathrm{H}_{0}$ diterima sehingga ada hubungan yang bermakna antara variabel kegiatan waktu luang dengan perilaku seksual berisiko IMS.

Hasil penelitian ini serupa dengan hasil pada penelitian Ika Nur Chaerani yang menunjukkan bahwa sebagian besar responden dari SMA Negeri 1 Baturraden (65.6\%) melakukan aktivitas yang beresiko untuk mengisi waktu luangnya. Hal yang perlu diperhatikan dalam hasil penelitian ini adalah sebagian besar responden (93.6\% responden dari SMA Negeri 1 Baturraden) menyatakan minimal pernah menonton atau membaca pornografi. Hal ini sangat mengkhawatirkan, karena dapat 
memicu terjadinya perilaku seksual pranikah pada remaja. Pada hasil penelitian tentang perilaku seksual remaja SMU di Surakarta menyebutkan alasan remaja melakukan hubungan seksual adalah karena pengaruh lingkungan, VCD, dan film porno, serta alasan kemajuan jaman dan supaya gaul. Seperti halnya siswa pada penelitian Ika Nur Chaerani, petani/ pedagang bawang pada penelitian ini juga memiliki resiko yang besar perlaku seks. Hal ini terjadi karena sebagian besar responden yang merupakan pedagang bawang melakukan kegiatan yang mengarah kepada perilaku seksual berisiko dalam mengisi waktu luangnya. Kegiatan ini diperkuat lagi dengan penghasilan yang didapatkan oleh pedagang / penjual bawang merah yang melebihi pendapatan rata-rata. Sehingga akses untuk melakukan kegiatan yang mengarah pada perilaku seksual berisiko juga sangat mudah dan memungkinkan. (Andisti,2008).

\section{Sikap terhadap seksualitas}

Sikap terhadap seksualitas yaitu tanggapan responden terhadap masalah yang berkaitan dengan seks dengan WPS, jumlah pasangan WPS, penularan, pencegahan dan pengobatan penyakit IMS dan AIDS serta pendapat tentang pemakaian kondom. Pada penelitian ini dari sebesar $26 \%$ responden menunjukkan sikap yang permisif terhadap pernyataan yang menyebutkan bahwa masturbasi adalah perilaku seksual yang biasa. perilaku seksual berisiko lebih banyak terdapat pada kelompok responden dengan sikap terhadap seksualitas yang kurang berisiko sebanyak 89,7\%. Hasil uji chi square didapatkan $p$ value $=0,403$ dimana $p$ $>0,05, \mathrm{H}_{0}$ diterima sehingga tidak ada hubungan yang bermakna antara variabel sikap terhadap seksual dengan perilaku seksual berisiko IMS.

Hasil penelitian ini sesuai dengan penelitian yang dilakukan Lestari pada 2014 di Semarang yang menyatakan bahwa tidak ada hubungan antara sikap dengan perilaku seksual. Begitu pula hasil studi yang dilakukan pada kelas III SMU Negeri Cirebon yang menyatakan tidak ada hubungan antara sikap dengan perilaku seksual pada penelitian Juleha pada tahun 2012. Akan teteapi penelitian ini tidak sesuai dengan penelitian Muhammad Azinar menunjukkan ada pengaruh yang signifikan antara sikap dengan perilaku seksual pranikah berisiko. Hal ini juga tidak sesuai dengan hasil penelitian dari BKKBN yang menyatakan bahwa dalam sikap permisif $40 \%$ tidak keberatan pacaran dengan saling rangkulan, 30\% tidak keberatan pacaran dengan saling pelukan, 20\% tidak keberatan pacaran dengan saling ciuman, $35 \%$ remaja pria tidak perlu mempertahankan keperjakaannya, $10 \%$ remaja wanita tidak perlu mempertahankan keperawanannya 
dan ngobrol saja adalah gaya pacaran lama 95\%. Sedangkan dalam sikap tidak permisif $60 \%$ keberatan dengan gaya pacaran saling berpegangan. Penelitian ini tidak sesuai dengan teori L. Green yang menyatakan bahwa faktor predisposisi dalam hal ini sikap berhubungan dengan perilaku seseorang. Sikap merupakan predisposisi (penentu) yang memunculkan adanya perilaku yang sesuai dengan sikapnya. Sikap tumbuh diawali dari pengetahuan yang dipersepsikan sebagai suatu hal yang baik (positif) maupun tidak baik (negatif), kemudian diinternalisasikan ke dalam dirinya. (Green, 2000).

\section{Religiusitas}

Religiusitas adalah tingkat ketaatan responden dalam menjalankan kewajiban agama dan keterlibatan responden dalam kegiatan-kegiatan keagamaan. Pada penelitian ini responden yang memiliki tingkat religius baik yaitu sebanyak 50,8\%. Pada penelitian perilaku seksual berisiko lebih banyak terdapat pada kelompok responden dengan tingkat religius yang kurang sebanyak $91,5 \%$ dibandingkan responden kelompok responden dengan dengan tingkat religius yang baik sebanyak $83,6 \%$. Hasil uji chi square didapatkan $p$ value $=0,190$ dimana $p>0,05, \mathrm{H}_{0}$ diterima sehingga tidak ada hubungan yang bermakna antara variabel religiusitas dengan perilaku seksual berisiko IMS.
Para ahli yang menyatakan bahwa ada hubungan negatif antara keagamaan dengan hubungan seks pranikah seperti halnya pada perilaku penyimpang. Agama membentuk seperangkat moral dan keyakinan tertentu pada diri seseorang. Melalui agama seseorang belajar mengenai perilaku bermoral yang menuntun mereka menjadi anggota masyarakat yang baik. Seseorang yang menghayati agamanya dengan baik cenderung akan berperilaku sesuai dengan norma. Hal ini juga sesuai dengan teori yang menyatakan bahwa faktor predisposisi dalam hal ini religiusitas yang diwujudkan dalam bentuk praktik menjalankan aktivitas keagamaan berhubungan dengan perilaku seseorang.(Riwidigdo, 2007).

\section{Sikap teman}

Sikap teman adalah sikap dan perilaku teman kerja terhadap perilaku seksual yang dapat mempengaruhi perilaku seksual responden. Pada penelitian ini sebagian besar responden yang memiliki sikap teman tidak permisif yaitu sebanyak $55,8 \%$. Berdasarkan hasil tabulasi silang yang memiliki perilaku seksual berisiko lebih banyak terdapat pada kelompok responden dengan sikap teman yang baik sebanyak $88,1 \%$ dibandingkan responden kelompok responden dengan sikap teman yang kurang baik sebanyak 86,6\%. Hasil uji chi square didapatkan $p$ value $=0,835$ dimana $p>0,05, \mathrm{H}_{0}$ diterima sehingga 
tidak ada hubungan yang bermakna antara variabel sikap teman dengan perilaku seksual berisiko IMS.

Kondisi ini menunjukkan bahwa pengalaman dan pandangan dari teman ini tidak jarang akan dapat mempengaruhi sikap dari teman sebaya lainnya. Hal ini dimungkinkan karena teman sebagai tempat untuk bertanya seputar masalah seks dimana mereka baru sama-sama merasakannya sekarang. Interaksi dan komunikasi dengan teman lebih sering terjadi jika dibandingkan dengan interaksi dengan orangtua. Seseorang akan lebih terbuka bercerita dan membahas permasalahan seksualitas dengan teman dekat atau teman sebayanya, sehingga informasi dan sikap dari teman tidak sedikit membawa pengaruh terhadap sikap seorang remaja. Hasil penelitian ini tidak sesuai dengan penelitian yang dilakukan oleh Puslitbang KB dan Kesehatan Reproduksi BKKBN yang menyatakan bahwa remaja yang mempunyai teman pernah melakukan hubungan seksual pra nikah dan mendorongnya untuk melakukan hubungan seksual pra nikah cenderung 1,8 kali lebih banyak bersikap setuju jika remaja melakukan hubungan seksual pra nikah daripada remaja yang tidak mempunyai teman pernah melakukan hubungan seksual pra nikah dan mendorongnya untuk melakukan hubungan seksual pra nikah. (Susanto, 2005).

\section{Akses Informasi}

Akses adalah sumber-sumber informasi tentang IMS dan HIV-AIDS yang diperoleh responden memalui media cetak, elektronik petugas kesehatan, sekolah dan teman. Pada penelitian ini sebagian besar responden yang tidak tersediannya akses informasi tentang IMS yaitu sebanyak 50,8\%. Berdasarkan tabulasi silang diketahui bahwa perilaku seksual berisiko lebih banyak terdapat pada kelompok responden dengan akses yang banyak sebanyak $88,5 \%$ dibandingkan responden kelompok responden dengan akses yang sedikit sebanyak $86,4 \%$. Hasil uji chi square didapatkan $p$ value $=0,730$ dimana $p>0,05, \mathrm{H}_{0}$ diterima sehingga tidak ada hubungan yang bermakna antara variabel akses dengan perilaku seksual berisiko IMS.

Hal ini sesuai dengan Sarlito, yang menyatakan bahwa remaja yang sedang dalam periode ingin tahu dan ingin mencoba, akan meniru apa yang dilihat atau didengarnya dari media massa, karena mereka belum pernah mengetahui masalah seks secara lengkap dari orang tua mereka sendiri. ${ }^{38)}$ Banyak peneliti yang mengakui bahwa tayangan media baik cetak maupun elektronik memberi kontribusi yang signifikan terhadap munculnya fenomena kematangan seksual sebelum waktunya. Ilmuwan North Caroline, Jane Brown meneliti remaja dengan eksploitasi seks di 
video klip, majalah dan televisi ternyata mendorong remaja melakukan aktivitas seks bebas.

Menurut Sarlito Wirawan, pendidikan seks paling banyak didapat dari media massa $58,81 \%$. Hal tersebut sesuai dengan peneliti dari North Caroline, yang secara umum remaja yang paling banyak mendapat dorongan seksual dari media cenderung melakukan seks pada usia 14 hingga 16 tahun 2,2 kali lebih tinggi di banding dengan remaja lain yang lebih sedikit melihat eksploitasi seks dari media. Hal ini tidak sesuai dengan teori L.W Green, media sebagai salah satu faktor pemungkin berhubungan dengan perilaku seksual. (Green, 2000)

\section{Fluktuasi Harga Bawang}

Fluktuasi harga adalah ketidaktetapan atau guncangan / naik turunya harga. Dalam penelitian ini diketahui bahwa responden yang kurang berpengaruh terhadap perilaku seksual yaitu sebanyak $65 \%$. Hasil tabulasi silang menunjukkan bahwa perilaku seksual berisiko lebih banyak terdapat pada kelompok responden dengan fluktuasi harga yang berpengaruh sebanyak $88,1 \%$ dibandingkan responden kelompok responden dengan fluktuasi harga yang berpengaruh sebanyak $87,2 \%$. Hasil uji chi square didapatkan $p$ value $=0,885$ dimana $p$ $>0,05, \mathrm{H}_{0}$ diterima sehingga tidak ada hubungan yang bermakna antara variabel fluktuasi harga dengan perilaku seksual berisiko IMS.

Fluktuasi harga bawang dipasaran tidak mempengaruhi perilaku seksual berisiko. Hal ini karena perilaku seksual merupakan segala bentuk perilaku yang didorong oleh hasrat seksual dari dalam tubuh, baik dengan lawan jenis maupun dengan sesama jenis. Perilaku seksual ini akan muncul ketika seseorang mampu mengkondisikan situasi untuk merealisasikan dorongan emosional dan pemikirannya tentang perilaku seksualnya atau sikap terhadap perilaku seksualnya. Banyak faktor yang mendorong seseorang untuk tetap melakukan perilaku seksual, termasuk yang berisiko. Diantaranya adalah faktor lingkungan dan adanya teman yang mendukung untuk berperilaku tersebut.

\section{Perilaku Seksual Berisiko IMS Pedagang}

\section{Bawang Merah}

Perilaku sesual beresiko adalah perilaku seksual responden yang terkena terhadap IMS yang meliputi seks dengan WPS, seks dengan pacar/teman, penggunaan kondom, dan jumlah pasangan seks. Pada penelitian ini diketahui responden yang berisiko IMS yaitu sebanyak 87,5\%. Perilaku berisiko seksual diketahui melalui pertanyaan apakah responden berhubungan seksual dengan PSK tanpa kondom dan didapatkan hasil 
$87,5 \%$ responden termasuk dalam kategori berisiko IMS.

\section{SIMPULAN}

Dari sejumlah 120 orang responden, diektahui bahwa sebgaian besar responden berusia $\geq 32$ tahun yaitu sebanyak 70,8\%, dengan pendidikan rendah sebanyak $57,5 \%$ dan penghasilan kurang dari Rp 120.000 sebanyak 55\%. Sebagian besar pengetahuan tentang HIV kurang baik sebanyak $56,7 \%$ dan memiliki kegiatan pengisi waktu luang yang beresiko IMS. Hasil analisis bivariat menunjukkan dari variabel yang diuji secara bivariat terdapat variabel yang berhubungan secara signifikan dengan perilaku berisiko IMS pada pedagang bawang merah adalah umur dan kegiatan pengisi waktu luang. Sedang variabel yang tidak berhubungan adalah pendidikan, pendapatan, status perkawinan, pengetahuan IMS, pengetahuan HIV/AIDS, sikap terhadap seksualitas, religiusitas, sikap teman, akses informasi dan fluktuasi harga bawang merah di pasaran.

Hasil analisis multivariat menunjukan, terdapat tiga variable yang signifikan berpengaruh terhadap perilaku seksual berisiko IMS yaitu kegiatan waktu luang dengan OR atau $\operatorname{Exp}(B)=6,160$ yang berarti bahwa responden yang mengisi waktu luangnya dengan kegiatan yang berisiko mempunyai kemungkinan 6,160 kali lebih besar untuk melakukan perilaku beresiko IMS. Religiusitas didapatkan nilai Odd Ratio (OR) atau Exp (B) $=3,509$, hal ini berarti bahwa responden yang tingkat religiusitasnya kurang mempunyai kemungkinan 3,509 kali lebih besar untuk melakukan perilaku beresiko IMS apabila dibandingkan dengan responden yang religiusitasnya baik. Sedangkan usia menjadi factor protektif perilaku seksual berisiko dengan OR atau $\operatorname{Exp}(B)=0,143$. Maka kegiatan waktu luang, religiusitas dan usia mempunyai peluang $33.16 \%$ dalam terjadinya perilaku seksual berisiko jika masing-masing variabel nilainya konstan.

\section{KEPUSTAKAAN}

Direktorat Jenderal Pemberantasan Penyakit Menular dan Penyehatan Lingkungan. Alat Kelamin dan yang Perlu Kita Ketahui tentang Infeksi Menular Seksual. Kementerian Kesehatan RI. Jakarta. 2011.

Direktorat Jenderal Pelayanan Medik dan Direktorat Jenderal Pemberatasan Penyakit Menular dan Penyehatan Lingkungan. Modul Pelatihan Konseling dan Tes Sukarela HIV untuk Konselor Profesional. Kementerian Kesehatan RI. Jakarta. 2013. 
Silitongga JT. Gambaran Infeksi Menular

Seksual di RSUD Medan (Skripsi).

Fakultas Kesehatan Masyarakat Universitas Sumatera Utara. Medan. 2009. Brotosaputro, B. 1988. Pengantar Pendidikan Penyuluhan Kesehatan Masyarakat. Fakultas Kesehatan Masyarakat Universitas Diponegoro. Semarang.

Direktorat Jenderal Pengendalian Penyakit dan Penyehatan Lingkungan. Surveilans Terpadu Biologis dan Perilaku Tahun 2010. Kementerian Kesehatan RI. Jakarta. 2011.

Dinas Kesehatan Provinsi Jawa Tengah. Profil Kesehatan Provinsi Jawa Tengah Tahun 2014. Dinas Kesehatan Provinsi Jawa Tengah. Semarang. 2014.

Dinas Kesehatan Kabupaten Brebes. Profil Kesehatan Kabupaten Brebes Tahun 2014. Dinas Kesehatan Kabupaten Brebes. Brebes. 2014.

Green LW and Kreuter MW. Health Promotion Planning An Educational and Environmetal Approach. Mayfield Publishing Company. Toronto. 2000.

Hakim DM. Faktor-Faktor yang Berhubungan dengan Kejadian Perilaku Seks Berisiko pada Remaja Tunarungu di Sekolah Menengah Atas Luar Biasa (SMALB) (Skripsi). Program Studi
Ilmu Kesehatan Masyarakat Fakultas Kedokteran Universitas Andalas. Padang. 2012.

Suryoputro A, dkk. Faktor-Faktor yang Mempengaruhi Perilaku Seksual Remaja di Jawa Tengah: Implikasinya Terhadap Kebijakan dan Layanan Kesehatan Seksual dan Reproduksi. Makara. 2006; 10(1): 29-40.

Arikunto. Prosedur Penelitian: Suatu Pendekatan Praktik. Rineka Cipta. Jakarta. 2006.

Budiarto E. Biostatistik untuk Kedokteran dan Kesehatan Masyarakat. EGC. Jakarta. 2003.

Riwidigdo H. Statistik Kesehatan. Mitra Cendekia Press. Yogyakarta. 2007.

Ririanti M. Faktor-Faktor yang Mempengaruhi Perilaku Seksual Beresiko Anak Jalanan di Kabupaten Jember Propinsi Jawa Timur (Tesis). Magister Promosi Kesehatan Program Pascasarjana Universitas Diponegoro. Semarang. 2009.

Andisti M. Religiusitas dan Perilaku Seks Bebas pada Dewasa Awal (Skripsi). Fakultas Kesehatan Masyarakat Universitas Indonesia. Jakarta. 2008. 